Editorial

\title{
Right-Wing Populist Party Organisation Across Europe: The Survival of the Mass-Party? Conclusion to the Thematic Issue
}

\author{
Stijn van Kessel ${ }^{1}$ and Daniele Albertazzi ${ }^{2, *}$ \\ ${ }^{1}$ School of Politics and International Relations, Queen Mary University of London, UK; E-Mail: s.vankessel@qmul.ac.uk \\ 2 Department of Politics, University of Surrey, UK; E-Mail: d.albertazzi@surrey.ac.uk \\ * Corresponding author
}

Submitted: 27 October 2021 | Published: 24 November 2021

\begin{abstract}
This article provides a comparative conclusion to the thematic issue on the organisational characteristics of 12 right-wing populist parties (RWPPs) across Europe. We observe that many RWPPs-at least partially-adopt features of the mass party model. This finding illustrates the ideological aspects behind organisational choices: For populist parties, in particular, it is important to signal societal rootedness and "closeness to the people." It furthermore challenges the idea that there is a one-way teleological movement towards more lean, electoral-professional kinds of party organisation. At the same time, the case studies clearly illustrate that RWPP leaders and executives continue to exercise great power over their members, who are essentially offered "participation without power."
\end{abstract}

\section{Keywords}

mass party; party membership; party organisation; populism; radical right

\section{Issue}

This editorial is part of the issue "Right-Wing Populist Party Organisation Across Europe: The Survival of the Mass-Party?" edited by Daniele Albertazzi (University of Surrey, UK) and Stijn van Kessel (Queen Mary University of London, UK).

(C) 2021 by the authors; licensee Cogitatio (Lisbon, Portugal). This editorial is licensed under a Creative Commons Attribution 4.0 International License (CC BY).

\section{Introduction}

By means of 12 case studies, this thematic issue has analysed how right-wing populist parties (RWPPs) across Europe organise themselves. In light of recent research on the importance of large and rooted party organisations for RWPP survival and success (Art, 2011; Heinisch \& Mazzoleni, 2016), we sought to interrogate the stillprevailing assumption that these parties rely on charismatic leadership to survive and thrive (e.g., Eatwell, 2018). More specifically, each contribution assessed whether individual RWPPs showed characteristics congruent with the "mass party" organisational model. In the introductory article (Albertazzi \& van Kessel, 2021), we outlined three key dimensions of the mass party: (a) the drive to recruit a large activist membership as a way to reach out to the public through canvassing, campaigning and other means; (b) rootedness on the ground and the provision of a variety of activities to members; and (c) the preservation of "collective identities through ideology" (Panebianco, 1988, p. 268), by creating closed political communities of activists, promoting social integration among them, and actively shaping their interpretations of political developments (Albertazzi, 2016). We also emphasised that actual membership numbers are not a defining criterion.

In the context of declining party membership and perceived elite disengagement from grassroots politics, several scholars have announced the demise of the mass party model and a shift towards, for instance, "catch-all" (Kirchheimer, 1966) and "cartel" (Katz \& Mair, 1995) parties. However, the adoption of mass party characteristics by several RWPPs, in particular, suggests that it may be too soon to herald the end of this party model. For these parties, the creation and fostering of closed communities of political activists can in fact lend credence to their populist claim that they are of, and for, ordinary people, and able to understand their needs and speak on their behalf. 
To be clear, not all RWPPs have chosen to adopt the mass party model-there are obvious examples of leader-centred and light-weight party organisations amongst this type of party, such as the Dutch radical right Partij voor de Vrijheid (PVV, Freedom Party) and the ideologically more moderate parties of Silvio Berlusconi in Italy and Andrej Babiš in the Czech Republic. Rather than assuming that all cases covered in this thematic issue are mass parties a priori, the contributors have assessed the extent to which, and how, a broad variety of RWPPs have invested in mass party structures. Bearing in mind that mass parties offer participation to members, but not necessarily meaningful influence (Duverger, 1951; Michels, 1962), the contributions also examined whether the selected RWPPs remained centralised in terms of their decision-making procedures, and whether opportunities were provided to members to shape their parties' direction and ideology. This concluding article highlights the key comparative findings from the 12 preceding articles.

\section{The Survival of the Mass Party Amongst Right-Wing Populist Parties?}

As our 12 case studies have indicated, a considerable number of RWPPs defy the common wisdom that such parties are organisationally light-weight and purely leader-centred. In many cases, RWPPs maintain an extensive structure with an institutionalised local presence, actively aiming to develop a grassroots following which is tied to the party by means of organised party activities. Several well-established RWPPs in Western Europe conform to the definition of the mass party, including the Lega per Salvini Premier (LSP, League for Salvini Premier) in Italy, the Vlaams Belang (VB, Flemish Interest) in Belgium, the Schweizerische Volkspartei/ Union Démocratique du Centre (SVP/UDC, Swiss People's Party) in Switzerland, and the Perussuomalaiset (PS, the Finns Party) in Finland (Favero, 2021; Hatakka, 2021; Sijstermans, 2021; Zulianello, 2021). Whilst some of these parties may rely on highly personalised campaigns centred on the leader-Salvini's League being a particularly good example-they maintain a high degree of organisational articulation, as well as vertical linkages to regional and local areas.

Some newer entrants in Western Europe are also found to defy received wisdom and adopt at least some characteristics of the mass party model. The Alternative für Deutschland (AfD, Alternative for Germany), for example, has lacked a single "charismatic" leader, and developed regional and local party branches across the country, as well as links with radical and extreme right social movement groups and online spheres (Heinze \& Weisskircher, 2021). The absence of a dominant leader and the presence of territorial penetration are also visible in the case of Vox in Spain. Even though organisational development and member recruitment remain geographically uneven, local and provincial branches are connected to the central level through vertical links (Barrio et al., 2021).

We also observe several RWPPs in Central and Eastern Europe investing in mass party structures or, at least, seeking to attain a "presence on the ground" and connecting with grassroots supporters. This is notable given the generally low levels of party membership and partisan alignment in post-communist party systems (van Biezen et al., 2012). Building on the foundation of a predecessor party, the Eesti Konservatiivne Rahvaerakond (EKRE, Estonian Conservative People's Party) has made efforts to re-activate and expand its local organisation, contributing to it being the fastestgrowing Estonian party in terms of its membership (Saarts et al., 2021). According to the analysis of Petar Bankov, Sergiu Gherghina and Nanuli Silagadze (Bankov et al., 2021), the VMRO-Balgarsko Natsionalno Dvizhenie (VMRO-BND, IMRO-Bulgarian National Movement) has also made conscious efforts to maintain strong links with local communities through activities that give it public visibility. Whilst formal membership numbers remain low and branch development limited, informal affiliations with a variety of like-minded far right and nationalist organisations enable the party to organise street actions, reach out to grassroots sympathisers, and recruit nominally independent candidates for public office. This more "fluid" connection with allied subcultures, the authors note, is quite typical of the radical right in Central and Eastern Europe, and not quite in line with the more formalised relationships in mass parties. In their contribution on the Hungarian case, Rudolf Metz and Réka Várnagy similarly note the role of informal networks. Describing the ideological and organisational transformation of Fidesz-Magyar Polgári Szövetség (FIDESZ, Fidesz-Hungarian Civic Alliance) in Hungary, they argue that the party has built a "hybrid" party organisation, "which demonstrates selected characteristics of mass parties, personal parties, movement parties, and even cartel parties" (Metz \& Várnagy, 2021, p. 318). Whilst not a typical example of a mass party, FIDESZ has aimed to strengthen its mobilisation capacity and collective identity-building in an attempt to take root in civil society, whilst simultaneously occupying the state.

To be clear, the contributions in this thematic issue do not point to a general and full-fledged revival of the mass party model across all RWPPs. This is illustrated by the above examples, but also by several other articles. In some cases the adoption of mass party characteristics remains partial and half-hearted, and largely driven by a desire to signal a "closeness to the people." Bartek Pytlas observes how the commitment of Prawo i Sprawiedliwość (PiS, Law and Justice) to organisational renewal and forging linkages with its supporter base has been largely rhetorical; the party "put little effort into actually recruiting a large number of engaged party members or fostering their social rootedness" (Pytlas, 2021, p. 341). In Slovakia, the efforts of the Slovenská Národná Strana (SNS, The Slovak 
National Party) to socialise members remained very limited, too, irrespective of a recent rise in membership numbers. Tim Haughton, Marek Rybár and Kevin Deegan-Krause conclude that "the party may have been more mass-like than many of the newer parties in Slovakia, but it fell well short of the mass party model" (Haughton et al., 2021, p. 330). In the Netherlands, the Forum voor Democratie (FvD, Forum for Democracy) appeared to divert from the extremely leader-centred organisational model of the longer-established PVV of Geert Wilders by seeking to build a large membership (de Jonge, 2021). Léonie de Jonge nevertheless observes that the party remained organisationally lightweight. Furthermore, after a period of extended organisational turmoil and defections, the FVD became increasingly dominated by its leader, Thierry Baudet, whilst efforts to engage and socialise members remained limited and selective.

What appears important in these latter parties' organisational choices is the desire to avoid complicating the management and internal structure of the party. Pytlas (2021) argues that, in the case of PiS, central and mid-level party leaders likely fear the undermining of existing power structures and the destabilising effects of letting in engaged members. Similarly, de Jonge (2021) notes that in the Netherlands the erstwhile architect of FvD's organisation, Henk Otten, was keen to limit the influence of partisan activists in order to prevent the internal instability that plagued the Dutch right-wing populist predecessor Lijst Pim Fortuyn (LPF, List Pim Fortuyn). It is obvious that some RWPPs, like other parties, prefer to adopt an "atomistic conception of party membership" (Katz \& Mair, 1995, p. 21) whereby supporters are affiliated directly with the central party, avoiding the potentially destabilising influence of intermediary subnational branches with unruly local leaders and activists.

Yet it is clear that a considerable number of RWPPs do build extensive party organisations and invest resources and time in attracting new members, and socialising existing ones. These parties consider the advantages of active membership: Members and sympathisers provide loyal support in elections and can deliver practical benefits, such as "feet on the ground" for election campaigns (Favero, 2021; Hatakka, 2021; Sijstermans, 2021; Zulianello, 2021). Yet at least as important appears to be the desire to gain an aura of authenticity and respectability. Even in cases where actual membership numbers remain low, like in the case of the Estonian EKRE, parties are keen to convey an image of being rooted in society and representing the ordinary "forgotten" people in local communities.

It is noteworthy that traditional means of interaction and communication remain important for these parties. Recruitment often happens through canvassing and street stalls. Parties organise in-person events for their members, such as political discussion meetings with invited speakers, training sessions on the eve of election campaigns, but also more informal social events (yearly festive meals, excursions, etc.) meant to strengthen cohesion and trust amongst members. Tõnis Saarts, Mari-Liis Jakobson, and Leif Kalev, for instance, describe how EKRE has active youth and women groups, as well as a choir (Saarts et al., 2021). As Adrian Favero and Judith Sijstermans observe in their case studies of Switzerland and Belgium, respectively, community building also involves the identification of "enemies," such as media organisations and established (left-wing) political parties (Favero, 2021; Sijstermans, 2021). The perception of being part of an ignored or ostracised community tends to feed an "us" versus "them" mentality that can strengthen intra-party cohesiveness.

In present-day mass parties, social media also tend to play an important role. Niko Hatakka, for instance, observes how the PS has a substantial online network of activists and sympathisers which is instrumental in increasing the party's societal presence (Hatakka, 2021). There are however also risks associated with this virtual form of mobilisation, in the sense that it creates more scope for organisational and ideological dissonance. In other cases, the internet also appears to play a vital role in the building of a "modern mass party." The VB is shown to extend its grassroots base beyond its formal membership via digital tools such as Facebook and mobile apps (Sijstermans, 2021), confirming the evolving nature of party membership (Scarrow, 2015). Mattia Zulianello similarly observes that continuous interaction between digital and physical activism allows the Italian League to nurture an image as a party firmly rooted in society (Zulianello, 2021). In the Spanish and Estonian cases, too, online platforms and communication have been instrumental to engaging, mobilising, and socialising activists and supporters (Barrio et al., 2021; Saarts et al., 2021). With respect to the German case, Anna-Sophie Heinze and Manès Weisskircher note the AfD's cooperation with "alternative media" platforms that have flourished in the German-speaking online sphere (Heinze \& Weisskircher, 2021). Not all RWPPs are equally tech-savvy, however; the SVP's digital communication, for instance, is mainly top-down and geared at conveying ideological messages instead of mobilising activists (Favero, 2021).

Altogether, the case studies suggest that many RWPPs see value in creating extensive organisational structures and building online and offline communities of loyal party members or more loosely affiliated adherents. As will become clear in the next section, however, adherence to the mass party model-whether wholly, partially, or rhetorically-does not imply giving members a meaningful voice in intra-party affairs.

\section{Centralisation of Power in RWPPs}

Even though a considerable number of RWPPs involve members in party activities and facilitate (online) platforms for discussion and interaction, the parties analysed in this thematic issue tend to be highly centralised, 
offering few opportunities to their members to influence key decisions about internal governance, choice of candidates, and ideological direction. Thus, these parties' strategies are typically dominated by their leader alongside a restricted group of representatives serving in the party executive. Whilst not all RWPPs have an unmistakable "charismatic" leader or a powerful chair operating behind the scenes-examples include the AfD and Vox - the central leadership is usually able to instruct and guide those at lower levels, and if need be to enforce internal discipline. In some cases, such as the Polish PiS, leadership is practically absolutist, whereby few key decisions are taken without the knowledge and consent of the chair, Jarosław Kaczyński (Pytlas, 2021).

Our cases do reveal some contextual idiosyncrasies. In the case of Spain, as Astrid Barrio, Sonia Alonso and Bonnie Field observe, power centralisation within the party is not only borne out of organisational and operational needs, but also in line with Vox's Spanish nationalist and state centralist ideology (Barrio et al., 2021). Efforts to centralise power inside the party have, however, provoked serious internal disputes and factionalism-something that has also happened in the case of the Dutch FvD. Conversely, in the case of the SVP/UDC, power centralisation is mitigated by the features of the Swiss political culture and federal system of government (Favero, 2021). The party maintains a highly centralised party apparatus at the national level, where a professionalised leadership has the ability to shape its ideology and key messages, but cantonal and local branches retain some degree of autonomy due to the highly decentralised political system.

Power centralisation in RWPPs almost automatically implies that the ability of ordinary members to influence party decisions tends to be limited. Representatives' informal responsiveness to local activists may in some cases give ordinary members more influence than official party rules suggest. Yet in almost all cases, levels of internal democracy tend to be low-this is certainly no different in the case of the Dutch Forum for Democracy, whose name therefore rings somewhat ironical (de Jonge, 2021). What is more, assemblies on which members are represented may formally be the supreme party organs, but in practice tend to have very few opportunities to affect the party's strategy or to shape its key policies. As the case of SNS illustrates particularly well, formal member prerogatives in the areas of policy formulation and candidate selection may prove rather meaningless in practice (Haughton et al., 2021). Across the cases, leadership elections are generally held, but these often have the character of a confirmatory vote rather than a genuine contest.

There is nevertheless some variation between the cases as well as across time. FIDESZ is a particularly notable case; Metz and Várnagy (2021) describe how it started out as an activist organisation adhering to principles of participatory democracy. Its authoritarian ideological turn and "capture" of the state in more recent years was accompanied by the dwindling of internal democracy, increased personalisation, and power concentration in the hands of Viktor Orbán and a small party elite in public office.

Amongst the cases in this thematic issue, EKRE, the $P S$, and the AfD appear to be the parties with currently the most developed, albeit still highly imperfect, infrastructures for internal democracy. Whilst EKRE displays a "clear preference for hierarchy over deliberation" (Saarts et al., 2021, p. 362), it is characterised by various power centres, and allows for grassroots initiatives and the election of personnel at various levels. In the case of Finland, Hatakka (2021, p. 304) argues that the PS is "organisationally a Frankenstein's monster," combining radically democratic elements in its congress and advisory assembly with a very powerful executive which faces little accountability. The German AfD appears to go somewhat further in offering genuine competition in terms of candidate selection and opportunities for members to influence party decisions. Heinze and Weisskircher (2021) argue that the party's relatively decentralised decision-making and collective leadership has come at the cost of constant intra-party conflict. The desire to prevent such internal turmoil appears to be a main reason why most other RWPPs shy away from even limited forms of internal democracy.

Generally speaking, then, RWPPs may claim to speak in the name of the "ordinary people" who have ostensibly been ignored by political elites, but this does not mean they give their members and activists a meaningful say over party affairs and ideological direction. This is no less the case for those RWPPs that adhere closest to the mass party organisational model.

\section{Conclusions}

Defying common wisdom about this type of party, and the direction of party evolution in general, many RWPPs analysed in this thematic issue are committed to maintaining rootedness on the ground. They continue to rely on activists or supporters to bring their message to the electorate and to facilitate the running of the party. In general terms, we have found that the existence of complex and rooted organisations usually allows party elites to shape members' interpretations of political developments in their countries, facilitating the creation of closed communities of like-minded members. Social media, far from being seen as an alternative to face-to-face interaction, are often essential to facilitate the organisation of in-person activities and face-to-face initiatives that allow members to interact both with the public and with each other.

There are clearly examples of lean and leadercentred party organisations among our cases. These parties seem to be mainly motivated by a desire to retain strict centralised control and avoid the cultivation of unruly local branches and activists. For most other parties considered in this thematic issue, however, the 
encouragement of traditional means of participation, involving actual encounters between people, is meant to lend credence to their populist claim that they are of, and for, ordinary people, and able to understand their needs and speak on their behalf. We see this as a contribution to the literature worth reflecting upon, given the tendency to study ideology and party organisations separately, when in fact there are important ideological aspects behind organisational choices. In other words, organisational choices can themselves be revealed to be "ideological products" (Scarrow, 2015, pp. 20-21).

Ultimately, the resilience of the mass party model challenges the idea that there is some sort of one-way, "one-size-fits-all" teleological movement towards "electoral-professional" forms of party organisation. For RWPPs, in particular, it makes sense to rely upon activism, rootedness on the ground, and the creation of communities of loyal members, both in practical terms (as ways to build effective campaigning machines) and ideologically (as means through which to strengthen narratives about parties allegedly being "close to the people"). For parties that place great importance on being seen to be different from the much criticised "cartel" of their opponents, presence on the ground and a growing membership suits their populist identity rather well.

As for how power is shared within organisations, this thematic issue has stressed the great influence that leaders and party executives continue to exercise over their members. The League and the VB provide the perfect case studies of RWPP mass parties in this respect, as they are disciplined, pyramidal, and run from the centre. Yet the same parties are also very able to foster participation and interaction between their members. Our articles thus point at the need to stop conflating internal democracy with the opportunity to take part in a variety of activities, interact with other members, discuss and interrogate political events, and possibly even criticise the choices made by party elites. If anything, much work remains to be done on why people are willing to keep donating their time, efforts, and sometimes money to organisations that - whilst certainly valuing what they do-are clearly not keen to let them have a say on strategy, alliances, and choice of candidates. As we challenge the dominant idea that political parties rely ever less on members (e.g., Katz \& Mair, 1995), we are therefore left with the question of what motivates party members to accept their parties' offer of participation without power (Albertazzi \& Vampa, 2021).

Clearly, there is still a serious gap in our knowledge about how party organisations operate, in particular regarding the role of members and activists (Gauja \& Van Haute, 2015). As far as its contribution is concerned, our thematic issue thus heeds calls for more comparative work to be produced on the way party organisations actually work, thus advancing our knowledge of what happens inside parties and suggesting new questions about the nature of political commitment and activism today.

\section{Acknowledgments}

The support of the Economic and Social Research Council (ESRC) is gratefully acknowledged (Grant Ref: ES/R011540/1). The authors would also like to thank the contributors of the thematic issue for their work and feedback, as well as Petra Guasti and Andrej Zaslove for their valuable comments on the project and individual case studies.

\section{Conflict of Interests}

The authors declare no conflict of interests.

\section{References}

Albertazzi, D. (2016). Going, going... not quite gone yet? "Bossi's Lega" and the survival of the mass party. Contemporary Italian Politics, 8(2), 1-16.

Albertazzi, D., \& Vampa, D. (2021). Populism in EuropeLessons from Umberto Bossi's Northern League. Manchester University Press.

Albertazzi, D., \& van Kessel, S. (2021). Right-wing populist party organisation across Europe: The survival of the mass-party? Introduction to the thematic issue. Politics and Governance, 9(4), 224-227.

Art, D. (2011). Inside the radical right: The development of anti-immigrant parties in Western Europe. Cambridge University Press.

Bankov, P., Gherghina, S., \& Silagadze, N. (2021). Walking the walk or just talking the talk? VMRO-BND's efforts to become a mass party. Politics and Governance, 9(4), 307-316.

Barrio, A., de Oger, S. A. S., \& Field, B. N. (2021). Vox Spain: The Organisational challenges of a new radical right party. Politics and Governance, 9(4), 240-251.

de Jonge, L. (2021). Is the (mass) party really over? The case of the Dutch Forum for Democracy. Politics and Governance, 9(4), 286-295.

Duverger, M. (1951). Les partis politiques [The political parties]. Armand Colin.

Eatwell, R. (2018). Charisma and the radical right. In J. Rydgren (Ed.), The Oxford handbook of the radical right (pp. 251-268). Oxford University Press.

Favero, A. (2021). Rootedness, activism, and centralisation: The case of the Swiss People's Party. Politics and Governance, 9(4), 252-262.

Gauja, A., \& Van Haute, E. (2015). Party members and activists. Routledge.

Hatakka, N. (2021). Between horizontality and centralisation: Organisational form and practice in the Finns Party. Politics and Governance, 9(4), 296-306.

Haughton, T., Rybář, M., \& Deegan-Krause, K. (2021). Leading the way, but also following the trend: The Slovak National Party. Politics and Governance, 9(4), 329-339.

Heinisch, R., \& Mazzoleni, O. (Eds.). (2016). Understanding populist party organisation. The radical right in 
Western Europe. Palgrave Macmillan.

Heinze, A.-S., \& Weisskircher, M. (2021). No strong leaders needed? AfD party organisation between collective leadership, internal democracy, and "movement-party" strategy. Politics and Governance, 9(4), 263-274.

Katz, R., \& Mair, P. (1995). Changing models of party organization and party democracy: The emergence of the cartel party. Party Politics, 1(1), 5-28.

Kirchheimer, O. (1966). The transformation of the Western European party systems. In J. LaPalombara \& M. Weiner (Eds.), Political parties and political development (pp. 177-200). Princeton University Press.

Metz, R., \& Várnagy, R. (2021). “Mass," “movement," "personal," or "cartel" party? Fidesz's hybrid organisational strategy. Politics and Governance, 9(4), 317-328.

Michels, R. (1962). Political parties: A sociological study of the oligarchical tendencies of modern democracies. The Free Press. (Original work published 1911)

Panebianco, A. (1988). Political parties: Organisation and power. Cambridge University Press.

Pytlas, B. (2021). Party organization of PiS in Poland: Between electoral rhetoric and absolutist practice. Politics and Governance, 9(4), 340-353.

Saarts, T., Jakobson, M.-L., \& Kalev, L. (2021). When a right-wing populist party inherits a mass party organisation: The case of EKRE. Politics and Governance, 9(4), 354-364.

Scarrow, S. (2015). Beyond party members. Oxford University Press.

Sijstermans, J. (2021). The Vlaams Belang: A mass party of the 21st century. Politics and Governance, 9(4), 275-285.

van Biezen, I., Mair, P., \& Poguntke, T. (2012). Going, going,... gone? The decline of party membership in contemporary Europe. European Journal of Political Research, 51(1), 24-56.

Zulianello, M. (2021). The League of Matteo Salvini: Fostering and exporting a modern mass-party grounded on "phygital" activism. Politics and Governance, 9(4), 228-239.

\section{About the Authors}
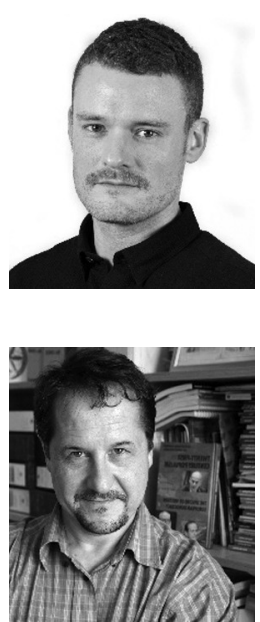

Stijn van Kessel is senior lecturer in European politics at Queen Mary University of London. His main research interests are populism and populist parties, as well as the politics of European integration. He is the author of Populist Parties in Europe: Agents of Discontent? (Palgrave, 2015) and of articles in journals including European Journal of Political Research, West European Politics, and Government \& Opposition. He is joint editor of the Routledge book series on Extremism \& Democracy.

Daniele Albertazzi is professor of politics at the Department of Politics of the University of Surrey. The major strands of his work have been about populism in Western Europe, party organisation, Italian politics, Swiss politics, and the communication strategies and mass media use of political parties. Daniele's most recent books are Populism and New Patterns of Political Competition in Western Europe (Routledge, 2021), co-edited with Davide Vampa, and Populism in Europe-Lessons from Umberto Bossi's Northern League (Manchester University Press, 2021), co-written with Davide Vampa. 